\title{
Botany
}

\section{Lemon maturation causes anatomical and biochemical changes at the flavedo tissue level}

\begin{tabular}{|r|l|}
\hline Journal: & Botany \\
\hline Manuscript ID & cjb-2021-0121.R1 \\
\hline Manuscript Type: & Article \\
\hline Date Submitted by the & $30-$ Aug-2021 \\
\hline $\begin{aligned} \text { Complete List of Authors: } \\
\text { Keyword: }\end{aligned}$ & $\begin{array}{l}\text { Albornoz, Patricia L.; FML } \\
\text { Zootecnia (UNT) } \\
\text { Hammann, Ariadna; Facultad de Ciencias Exactas y Naturales, } \\
\text { Departamento de Biología } \\
\text { Rosa, Mariana; INBIOFIV (CONICET-UNT) } \\
\text { Prado, Fernando ; INBIOFIV (CONICET-UNT) } \\
\text { Rapisarda, Viviana; INSIBIO (CONICET-UNT) } \\
\text { Hilal, Mirna; INBIOFIV (CONICET-UNT), Departamento de Biología }\end{array}$ \\
\hline $\begin{array}{r}\text { Is the invited manuscript for } \\
\text { consideration in a Special } \\
\text { Issue? : }\end{array}$ & \begin{tabular}{l} 
Not applicable (regular submission) \\
\hline
\end{tabular} \\
\hline
\end{tabular}

\section{SCHOLARONE ${ }^{\text {M }}$ Manuscripts}




\section{Lemon maturation causes anatomical and biochemical changes at the}

\section{flavedo tissue level}

Patricia L. Albornoz ${ }^{1}$, Roque Interdonato ${ }^{2}$, Ariadna Hammann ${ }^{3}$, Mariana Rosa ${ }^{4}$, Fernando E. Prado ${ }^{4}$, Viviana A. Rapisarda ${ }^{5 *}$ and Mirna Hilal ${ }^{3,4^{*}}$

${ }^{1}$ Anatomía Vegetal-Facultad de Ciencias Naturales e IML (UNT) and Instituto de Morfología Vegetal, Fundación Miguel Lillo, Miguel Lillo 205, Tucumán, Argentina.

${ }^{2}$ Fisiología Vegetal-Facultad de Agronomía y Zootecnia (UNT), Florentino Ameghino s/n, El Manantial, Lules, Tucumán, Argentina.

${ }^{3}$ Departamento de Biología-Facultad de Ciencias Exactas y Naturales (UNCa), Belgrano 300, Catamarca, Argentina.

${ }^{4}$ INBIOFIV (CONICET-UNT) and Fisiología Vegetal-Facultad de Ciencias Naturales e IML (UNT), Miguel Lillo 205, Tucumán, Argentina.

${ }^{5}$ INSIBIO (CONICET-UNT) and Instituto de Química Biológica “Dr. Bernabé Bloj”, Facultad de Bioquímica, Química y Farmacia (UNT), Chacabuco 461, Tucumán, Argentina.

*Corresponding authors,

Viviana A. Rapisarda viviana.rapisarda@fbqf.unt.edu.ar

Mirna Hilal mhilal@.csnat.unt.edu.ar 


\begin{abstract}
Plants mobilize the photosynthates by three transport pathways: apoplastic, symplastic through plasmodesmata (PD), and transcellular. In flavedo of postharvest mature lemons, a high activity of cell wall-bound invertase (WI), an enzyme associated with transcellular transport of monosaccharides, has been detected. In order to elucidate whether this high enzymatic activity is related to restricted transport in the symplastic pathway with fruit maturation, the aim of the present work was to compare anatomical and biochemical parameters in peel tissues of immature and mature lemons. Anatomical structure focusing on cell walls, callose deposition, WI activity, and sucrose content were analyzed in peel tissues of immature and mature lemons. The parenchyma of flavedo tissue of immature lemons presented an elevated number of primary pit fields (PPF). These PPF, associated to PD or cell wall interruptions, had the appearance of a string of beads. However, in mature lemons, the number of PPF was scarce due to callose deposition. WI activity and apoplastic sucrose content increased significantly in flavedo of mature lemons in comparison to immature lemons. Present findings lay structural and functional bases relevant to understand differences between immature and mature lemons, which would help to design agricultural practices in pre- and post-harvest management.
\end{abstract}

Key words: callose; cell wall-bound invertase; lemon peel; primary pit fields; sucrose

\author{
Abbreviations \\ PD Plasmodesmata \\ PPF Primary pit fields \\ WI Cell wall-bound invertase
}




\section{Introduction}

Water, carbohydrates, aminoacids, hormones and minerals are critical factors during the fruit growth (Iglesias et al. 2007; Tays et al. 2015). In plants, photosynthates are translocated from source organs (leaves) to sink organs through phloem. The main carbohydrate translocated during fruit development is sucrose, which can be directed to the formation of tissues, the synthesis of pigments and reserve substances, and the development of seeds, among others. The sugar amounts that reach the fruit depend on the strength of the sink, and are related to the degree of development, being high in actively growing fruit (Bustan et al. 1995).

The transport of substances in plants is carried out through three pathways: a) apoplastic, outside the plasma membrane; b) transcellular, by transporters or channels of the plasma membrane and endo/exocytosis; c) symplastic, through plasmodesmata (PD) that connect the cytoplasm of neighboring cells through interrupted regions of the cell wall. Primary pit fields (PPF) are thin areas of primary wall that may contain a different number of PD (Crang et al. 2018). Each PD is lined with plasma membrane and contains a narrow tubule, the desmotubule, which is a continuation of the endoplasmic reticulum (Taiz et al. 2015). Different morphotypes of PD have been described: single channel, complex channels (funnel type) (Roberts et al. 2001; Ross-Elliott et al. 2017) and channels with opaque appearance in mitotically active tissues (Nicolas et al. 2017). It has been reported that the intercellular flow of molecules through the symplastic pathway is regulated by both development and environmental factors (Benitez-Alfonso 2014; Sager and Lee 2014). In fact, plants respond to microbial pathogens by restriction of PD-mediated cell-to-cell communications (Lee 2015). Cell-tocell communication restriction involves endoplasmic reticulum membranes passing through PD channels and the deposition of callose [(1,3)- $\beta$-glucan polymer] in the neck region of PD (De Storme and Geelen 2014). However, detailed effects of callose deposition on structure and permeability of PD channels are scarce (Amsbury et al. 2018).

In the transcellular pathway, sucrose gets into sink cells through specific transporters (carriers) localized in the plasma membrane or after its apoplastic cleavage to hexoses (glucose and fructose) by a cell wall-bound invertase (WI). In a previous study, Interdonato et al. (2011) analyzed glucose, fructose and sucrose contents and enzyme activities associated to sucrose metabolism in peel tissues 
(albedo and flavedo) of a mature lemon after harvest. In the flavedo, very high WI activity was observed when compared to WI activity in albedo or to other sucrose-related enzyme activities [e.g. cytosolic invertase (CI), vacuolar invertase (VI), sucrose synthase (SS), and sucrose phosphate synthase (SPS)]. High WI activity in flavedo tissue has been associated with sugar uptake from albedo to support the active metabolism occurring in postharvest lemons (Interdonato et al. 2011). It has been also observed in our laboratory that both high respiratory activity (cytochrome and alternative pathways) and antioxidant capacity occurred in flavedo of postharvest lemons (Ruiz et al. 2016).

Based on these observations, we hypothesized that the increase in WI activity of mature lemon flavedo maintains the carbohydrate supply to this tissue through the transcellular pathway, since the symplastic pathway is limited or blocked, contrary to what occurs in immature lemons. To validate this hypothesis, the aim of the present work was to compare structural and biochemical features in peel tissues of immature and mature lemons.

\section{Materials and Methods}

\section{Plant material}

Lemons (Citrus limon (L.) Burm. var. Eureka) were hand-collected from a commercial orchard (Tucumán, Argentina $26^{\circ} 50^{\prime} \mathrm{S}$ and $65^{\circ} 12^{\prime} \mathrm{W}$ ). Immature (green) lemons were harvested at 4 months from fruit set (February, summer season) and mature (yellow) lemons at 8 months from fruit set (June, autumn season). Samples correspond to Stage II (rapid growth, cell enlargement) and to the end of Stage III (maturation period) of the typical sigmoidal curve of citrus fruit development, previously reported by Bain (1958). For each condition, 50 lemons from 25 randomly distributed healthy trees were picked at $60-100 \mathrm{~cm}$ from the canopy periphery and at $130-180 \mathrm{~cm}$ above the ground. Lemons were washed with distilled water and stored at $25^{\circ} \mathrm{C}$ prior to chemical and anatomical studies.

\section{Anatomy of lemon peel and ultrastructure of flavedo tissue}

Transversal sections of lemon peel from the equatorial zone of the fruit were fixed in Karnovsky's solution (4\% formaldehyde, 5\% glutaraldehyde and $0.1 \mathrm{M}$ sodium phosphate buffer, $\mathrm{pH} 7.4$ ) (Karnovsky 1965), and post fixed with $1 / 1$ solution of sodium phosphate buffer with $2 \%$ osmium 
tetroxide. After incubation with both fixatives at $4^{\circ} \mathrm{C}$ overnight, samples were washed, embedded in Spurr resin, cut with an ultra-microtome to obtain thin $(3 \mu \mathrm{m})$ and ultrathin $(100 \mathrm{~nm})$ sections. To characterize the anatomical structure of lemon peel, the thin sections were stained with $0.05 \%$ toluidine blue (Heslop-Harrison and Heslop-Harrison 1981) and observed using an optical microscope (Carl Zeiss, Axiostar plus, Göttingen, Germany). The ultrathin sections of flavedo tissue were mounted on copper grids and contrasted with uranyl acetate and lead citrate (Venable and Coggeshall 1965) for observation with a transmission electron microscope (Carl Zeiss, EM109, NTS GmbH, Oberkochen, Germany) from the Centro Integral de Microscopía Electrónica (CIME-CONICET, Tucumán, Argentina).

Unfixed free hand transversal sections of lemon peel samples from the equatorial zone were also analyzed. In those studies, a stereomicroscope (Olympus SZX7, Olympus Co., Tokyo, Japan) was used to clear and stain samples, as well as to assemble the slides. Samples unstained or stained with 0.5\% blue astra-safranin (Zarlavsky 2014) were examined using a light microscope (Carl Zeiss, Axiostar Plus, Göttingen, Germany) coupled to a digital camera (Canon A620, Power Shot 7.1MP). In transversal sections of flavedo parenchyma stained with the blue astra-safranin to denote nonlignified primary walls, the number of PPF per cell was determined. Starch grains were observed using a polarized light microscope (Carl Zeiss, Axio Lab. A1, Göttingen, Germany) and the microphotographs were taken with Olympus SP-350 8MP camera. Analyzed slides were deposited at the Institute of Plant Morphology of the Miguel Lillo Foundation, Tucumán, Argentina.

\section{Callose detection}

In order to analyze callose deposition in phloem sieve plates of the lemon peduncle region, free hand longitudinal sections were stained with $1 \%$ brilliant cresyl blue (D'Ambrogio de Argüeso 1986). Samples were examined using a light microscope (Carl Zeiss, Axiostar Plus, Göttingen, Germany) and the microphotographs were taken with a digital camera (Canon A620, Power Shot 7.1MP).

For callose detection in flavedo parenchymatic cells, the technique of Martin (1959) with minor modifications was carried out. Briefly, transversal sections of flavedo tissue were cleared with $50 \%$ $\mathrm{NaClO}$ and then stained with $0.05 \%$ aniline blue in $0.15 \mathrm{M} \mathrm{KH}_{2} \mathrm{PO}_{4}$. Callose deposition was observed 
using an epifluorescence microscope (Olympus BX 43 U-TVO 5xc-3, UV-365nm filter) coupled to a camera (Olympus Qcolor 5 RTV, 5MP, Ontario, Canada).

\section{Cell wall-bound invertase activity}

Cell wall-bound invertase (WI) was extracted from albedo and flavedo tissues according to Interdonato et al. (2011). Briefly, $1.5 \mathrm{~g} \mathrm{FW}$ of powdered tissue was homogenized using a chilled mortar and pestle with $5 \mathrm{ml}$ of $50 \mathrm{mM}$ sodium phosphate buffer (pH 7.5) containing $5 \mathrm{mM} \mathrm{MnSO}_{4}$ and $1 \mathrm{mM} \beta$-mercaptoethanol. The homogenate was centrifuged at $12,000 \times \mathrm{g}$ for $15 \mathrm{~min}$ and the supernatant was discarded. The pellet was washed 5 times with $10 \mathrm{mM}$ sodium acetate buffer ( $\mathrm{pH} 5.5$ ) containing $1 \mathrm{mM} \beta$-mercaptoethanol. After centrifugation at $12,000 \times \mathrm{g}$ for $15 \mathrm{~min}$ the pellet was resuspended in few $\mathrm{ml}$ of washing buffer and dialyzed for $3 \mathrm{~h}$ in two changes of the same buffer. The dialyzed suspension was used as the enzyme source. Enzyme extraction was carried out at $4{ }^{\circ} \mathrm{C}$. To solubilize WI, the enzyme preparation was treated successively with detergent, high salt concentrations, chelating and chaotropic agents, as described by Podazza et al. (2006). Invertase activity was assayed according to Rosa et al. (2004) by incubating a reaction mixture $(100 \mu 1)$ containing $200 \mathrm{mM}$ sodium acetate buffer (pH 5.5), $60 \mathrm{mM}$ sucrose, $1 \mathrm{mM} \beta$-mercaptoethanol, and the enzyme extract. After incubation at $37^{\circ} \mathrm{C}$ for $30 \mathrm{~min}$, released reducing sugars were determined by the method of Nelson (1944). The enzyme activity was expressed as mmol reducing sugars $\min ^{-1} \mathrm{~g}^{-1} \mathrm{FW}$. All assays included control reactions in the absence of sucrose.

\section{In situ sucrose localization and content}

In situ sucrose localization was adapted from Martinelli (2008) according to Birnberg and Brenner (1984). The enzymatic reactions linked sucrose presence to $\mathrm{NAD}^{+}$reduction via glucose-6-phosphate dehydrogenase. The produced NADH reacted with iodonitrotetrazolium (INT), yielding the red insoluble INT-formazan. Free-hand transversal sections of fresh lemon peel were soaked for $15 \mathrm{~min}$ at room temperature in solutions containing the required coupling enzymes and cofactors. The staining solution was composed of $100 \mathrm{mM}$ phosphate buffer (pH 7.5), $20 \mathrm{mM} \mathrm{MgCl} 2,10 \mathrm{mM}$ EDTA, $0.8 \mathrm{mM}$ $\mathrm{NAD}^{+}, \quad 11.2 \mathrm{U} / \mathrm{mL}$ glucose-6-phosphate dehydrogenase from L. mesenteroides, $24 \mathrm{U} / \mathrm{mL}$ 
phosphoglucomutase from rabbit muscle, $4 \mathrm{U} / \mathrm{mL}$ sucrose phosphorylase from $L$. mesenteroides and saturated with 3-(3,4-dichlorophenyl)-1,1-dimethylurea and INT. Controls consisted of sections soaked for $15 \mathrm{~min}$ in a solution lacking sucrose phosphorylase. Images were taken immediately after incubation using a microscope (Carl Zeiss, Axiostar Plus, Göttingen, Germany) coupled to a digital camera (Canon A620, Power Shot 7.1MP).

Sucrose content was determined in flavedo samples (as total and symplastic contents) by the method of Roe and Papadopoulos (1954) after eliminating free fructose from the extracts (Cardini et al. 1955). Sucrose was extracted from flavedo $(0.5 \mathrm{~g})$ following the method described by Prado et al. (2000). To obtain the symplastic sucrose, samples were cut into 5-mm long sections and rinsed in distilled water 7-8 times to eliminate apoplastic sucrose. The apoplastic sucrose was calculated as the difference between total and symplastic sucrose.

\section{Statistical analysis}

Statistical differences in enzyme activities and sucrose contents were determined by analysis of variance (ANOVA) followed by the Tukey's test $(\mathrm{p}<0.01)$. Each anatomical analysis was performed using 5 immature and 5 mature lemons. The number of PPF per cell was quantified in 7 cells of 3 different sections from each fruit. Values were expressed as means \pm SD and were compared using Student's $t$ tests. Correlation between number of PPF per cell and WI activity was estimated using Pearson correlation coefficient.

\section{Results}

\section{Anatomical characterization of lemon peel}

Immature green lemons used in this work were approximately $40-50 \%$ smaller than mature yellow lemons, with fruit diameters of $4.0 \pm 0.5$ and $7.1 \pm 0.5 \mathrm{~cm}$, respectively (Fig. 1A). Lemon fruit is a hesperidium berry with a peel, consisting of the epicarp (colored flavedo) and the mesocarp (white albedo). According to the previous data, flavedo tissue is composed of parenchymatic cells rich in chloro- or chromoplasts (Ford 1942; Huff 1983, 1984; Matas et al. 2010). Due to the scarce information on the anatomy of lemon peel, a first step in our studies was to make a detailed 
histological description to define limits of each particular tissue and to improve our knowledge of its structure. Fig. 1B shows the structure of mature lemon peel, where both the flavedo and albedo are distinguishable. The flavedo was observed to consist of a cuticle (smooth and thin), an epidermis (1 cellular layer) with dispersed stomata, collenchyma (3-4 cellular layers) with thickenings in tangential walls of contiguous cells, and parenchyma (3-5 cellular layers). Immediately below the flavedo was the albedo, consisting of numerous layers of parenchymatic cells and dispersed vascular bundles. Essential oil cavities were observed extending through both tissues. Simple starch grains with eccentric hilum were visualized only in the albedo tissue (Fig. 1B, inset), while calcium oxalate crystals were present only in the flavedo tissue. Unstained fresh sections of flavedo of immature and mature lemons are shown in Fig. 1C and D, respectively. These images of the external cell layers of lemon peel confirmed the depth of flavedo or coloured tissue. Green or yellow colours, denoting the presence or the absence of chlorophyll, were observed in immature and mature lemons, respectively. No significant differences in the number of cell layers were observed comparing both samples. However, differences in cell structure were observed, as described below.

\section{Cell wall interruptions in flavedo and albedo parenchymatic cells}

In immature lemons, flavedo parenchyma cell walls exhibited a noticeable discontinuity which resembles beads on a string (Fig. 2). This characteristic was due to the large number of PPF (Fig. 2A, C). The inset in Fig. 2C shows striations near the cell wall, which can be related with the intercellular flow via PD. In mature lemons, flavedo parenchymatic cells presented homogeneous walls with scarce interruptions (Fig. 2B, D), indicating possible PD closure. Indeed, the number of PPF per cell in transversal sections of flavedo parenchyma were $20.18 \pm 3.14$ and $3.97 \pm 3.29$ in immature and mature lemons, respectively $(p<0.0001)$. Albedo of both lemons did not present significant structural differences, showing discontinued cell walls resembling beads on a string, due to the presence of abundant PPF (Fig. 3A, B).

\section{Callose deposition in flavedo parenchymatic cells and peduncle region}


Scars in certain sectors in the flavedo parenchyma of mature lemons were visualized using transmission electron microscopy, indicating the closure of PD-associated wall interruptions (Fig. 4B). On the other hand, wall interruptions were clearly observed in immature lemon flavedo (Fig. 4A). Callose deposits were observed after specific staining with epifluorescence microscopy and appeared as bright dots and lines through the cell walls in mature lemons (Fig. 4D) or as small dots of low brightness in immature lemons (Fig. 4C). Longitudinal sections of the peduncle were analyzed to determine the vascular connection of both mature and immature lemons to the plant (Fig. 5). Sieve plates of phloem elements were blocked by callose deposits in mature lemons (Fig. 5B), while callose deposits were not observed in immature fruit (Fig. 5A).

\section{Cell wall-bound invertase activity in lemon peel tissues}

Closure of PD associated to PPF in mature lemons may lead to limited transport in the symplastic pathway of the flavedo tissue. In order to elucidate if this could be related to an increase in transcellular pathway, the activity of cell wall-bound invertase (WI) was determined in albedo and flavedo of immature and mature lemons (Fig. 6). WI activity in albedo tissue did not differ significantly with lemon maturity, with values around $0.08 \mu$ mol reducing sugars $\min ^{-1} \mathrm{~g}^{-1} \mathrm{FW}$. In contrast, WI activity in the flavedo of immature lemons was 0.16 compared to $1.18 \mu$ mol reducing sugars $\min ^{-1} \mathrm{~g}^{-1} \mathrm{FW}$ (more than 7-fold higher) in mature lemons. In the flavedo tissue, a negative correlation occurred, as the number of PPF per cell decreased and the WI activity increased (Pearson coefficient, $\mathrm{r}=-0.98 ; p<0.001)$

\section{Localization and content of sucrose in lemon peel}

Following the identification of differences in the number of PPF and WI activity in flavedo from immature and mature lemons, the localization and content of sucrose were also analysed for both developmental stages. The presence of sucrose in lemon peel was notably higher in mature compared to immature fruit (Fig. 7A-D). The highest staining intensity was observed both in flavedo and in cells surrounding the oil vesicles of mature lemons (Fig. 7B, D). In flavedo of mature lemons, apoplastic 
sucrose content was more than 3 -fold higher than symplast content; while in immature lemons the values were low and similar in both compartments (Fig. 7E).

\section{Discussion}

The flavedo parenchyma of mature lemons exhibited continuity of their cell walls and high WI activity, contrary to immature lemons. These results provide evidence that lemon maturation is accompanied by both a blockage of symplastic transport pathway (by closure of PD) and an increased in the transcellular pathway of hexoses transport in flavedo tissue.

The peel of different citrus fruit is similar, formed by flavedo and albedo tissues; however, the description of cellular types and layers in citrus peel has been scarcely detailed. Some anatomical descriptions of citrus peel were previously reported (Medeira et al. 1999; Matas et al. 2010). The present study reports the number of tissue layers that compose the lemon peel, describing for the first time the presence of subepidermal collenchyma. Fruit flavedo consisted of three cellular components: epidermis, collenchyma, and parenchyma. Collenchyma showed thickenings in tangential walls of contiguous cells, corresponding to lamellar collenchyma based on the Fanh classification (Fanh 1985). The decrease in the number of PPF in flavedo parenchymatic cells of mature lemons was associated with the closure of PD by callose deposits and the presence of scars in certain sectors. Amsbury et al. (2018) proposed a hypothetical model for the regulation of symplastic transport in that callose deposition decreases the cytoplasmic aperture of PD and reduces molecular flux. The role of callose in the PD closure in the PPF during maturation may not be exclusive, since other structural components of the cell wall, such as cellulose or pectin, can also be involved. In mature lemons, the decrease in the number of PPF was correlated with the appearance of callose deposits in the sieve plates of the peduncle phloem tubes. It is known that during the early process of fruit abscission at maturity, the phloem pathway is interrupted at the level of the insertion of the peduncle by callose deposition in sieve plates (Taiz et al. 2015). Merelo et al. (2017) identified genes involved in this process in citrus fruit. Callose deposition during fruit maturation corresponds to an irreversible process. While callose deposition as stress responses or signal mechanisms has been associated to a reversible process catalyzed by inducible (1,3)- $\beta$-glucanases (De Marco et al. 2016; Amsbury et al. 2018), our work 
shows that it is an irreversible process. At the end of lemon fruit maturation, a callose synthase could possibly be involved in the closure of both the phloem tube elements at the level of the peduncle and the PD of flavedo parenchymatic cells.

In citrus fruit, the photosynthates arrive via phloem through the peduncle and are delivered to the exterior of each section (carpel) via three vascular bundles: central, dorsal and septal, to provide nutrients to juice vesicles and seeds (Koch and Avigne 1990; Sadka et al. 2019). Vascular bundles and starch deposits were absent in flavedo tissue, whereas they were found in albedo tissue. In fact, transport through lemon peel is mediated by vascular bundles that reach the albedo and by nonvascular transport (symplastic, apoplastic and transcellular pathways), that channel the photosynthates to both the albedo and flavedo.

A high concentration of sucrose was detected in the apoplastic space of flavedo in mature lemons. This fact could be related to PD closure among other reasons. Accumulated sucrose in the peel of mature fruit can be relevant to color development and to maintain the osmotic potential of the tissue, which in turn could protect fruit against dehydration and low temperatures. In addition, it should be noted that the sucrose requirement in flavedo of mature lemons is lower than that in immature lemons, which demand high carbon supply for growth, as previously described (Bain 1958; Huff 1983, 1984; Iglesias et al. 2007).

Integrating the anatomical and biochemical results, a scheme of the transport pathways of photosynthates in the peel of immature and mature lemons is proposed (Fig. 8). In immature lemons, phloem tubes allow movement of photosynthates from the plant to growing fruit. At the cellular level, the apoplastic, transcellular, and symplastic pathways are active, providing a high degree of communication between cells. In the case of mature lemons, phloem tubes are closed in the peduncle that connect the fruit and shoot, interrupting the communication with plant. Furthermore, PD of flavedo parenchymatic cells are blocked, canceling the symplastic pathway and leading to increases in WI activity related to the transcellular pathway. Albedo of both immature and mature lemons showed abundant PPF associated to PD and low WI activity (Fig. 8).

According to the proposed model (Fig. 8), the transport of photosynthates to peel tissues depends on both fruit maturation stage and tissue type. The lemon, as a fruit, is a sink organ of the plant; however, 
some particularities must be considered. Immature lemons are strong carbon sinks, while mature lemons cease to receive assimilates from the plant, due to blockage of the phloem elements in the peduncle. Tissues of the lemon peel have different roles with respect to the distribution of assimilates according to the developmental stage. Albedo, which contains starch grains, plays a key role as a source of carbon precursors for flavedo metabolism in mature lemons, when the fruit-plant communication is interrupted (see Fig. 5). It is important to note that the peel of the mature lemons has metabolic activity even after harvest. In fact, the peel of postharvest lemons is capable of reacting to stimuli such as exposure to supplemental UV-B radiation. After UV-B irradiation, there is carbohydrate movement from albedo to flavedo, increasing the fructose and glucose contents in the flavedo tissue (Interdonato et al. 2011). In this scenario, the movement of hexoses between the albedo and flavedo and the modification of enzyme activities associated with sucrose metabolism may contribute to the biosynthesis of secondary metabolites (such as flavonoids and phenolic compounds), to thicken the cell wall and to reduce the incidence of green mold disease (Interdonato et al. 2011; Ruiz et al. 2016).

\section{Conclusions}

Our study demonstrated that, as we hypothesized, there is limited symplastic pathway in flavedo of mature lemons, and carbohydrates supply is maintained by an increase in the WI activity. To our knowledge, this is the first evidence of structural changes in the flavedo parenchyma cell wall, showing a decrease in the number of PPF and a closure of PD during lemon fruit maturation. Callose deposits in mature lemons to close PD and to block phloem elements at the level of the peduncle are possibly coordinated by endogenous signals during late stages of maturation and at the beginning of senescence/abscission. These changes and the accumulation of sucrose could protect the fruit from deleterious effects of stress factors and from dehydration by limiting water/electrolyte loss. Present findings contribute to anatomical and physiological knowledge of lemon fruit at different maturation stages. Our data could be helpful to design agricultural practices in pre- and post-harvest management, in order to improve quality and health of lemons. 


\section{Author statements}

\section{Acknowledgements}

We thank Lelia Bordón from Sección Iconografía (Fundación Miguel Lillo) for her assistance in graphical design.

\section{Competing interests' statement}

The authors declare there are no competing interests.

\section{Contributors' statement}

PLA, FEP, VAR, and MH planned and designed the research. PLA, RI, and MR performed experiments and conducted fieldwork. PLA, RI, MR, AH, FEP, VAR, and MH analyzed and interpreted data. PLA, VAR, and MH wrote the manuscript. VAR and MH equal contributed as corresponding authors.

\section{Funding statement}

This work was supported by grants B-0002-1 from Fundación Miguel Lillo (FML), PICT2016-0595 from Agencia Nacional de Promoción Científica y Técnica (ANPCyT-MINCYT), and PIUNT 2018/D627 from Universidad Nacional de Tucumán (UNT).

\section{Data availability statement}

All data generated or analysed during this study are included in this published article.

\section{References}

Amsbury, S., Kirk, P., and Benitez-Alfonso, Y. 2018. Emerging models on the regulation of intercellular transport by plasmodesmata-associated callose. J. Exp. Bot. 69: 105-115.

Bain, J.M. 1958. Morphological, anatomical; and physiological changes in the developing fruit of the valencia orange, Citrus sinensis (L.) Osbeck. Aust. J. Bot. 6: 1-24. 
Benitez-Alfonso, Y. 2014. Symplastic intercellular transport from a developmental perspective. J. Exp. Bot. 65: 1857-1863.

Birnberg, P.R., and Brenner, M.L. 1984. A one-step enzymatic assay for sucrose with sucrose phosphorylase. Anal. Biochem. 142: 556-61.

Bustan, A., Erner, Y., and Goldschmidt, E.E. 1995. Interaction between developing citrus fruits and their supportive vascular system. Ann. Bot. 76: 657-666.

Cardini, C., Leloir, L.F. and Chiriboga, J. 1955. The biosynthesis of sucrose. J. Biol. Chem. 214: 149155.

Crang, R., Lyons-Sobaski, S., and Wise R. 2018. Plant anatomy, a concept-based approach to the structure of seed plants. Springer Nature Switzerland AG, Switzerland.

D’Ambrogio de Argüeso, A. 1986. Manual de técnicas en histología vegetal. Editorial Hemisferio Sur SA, Buenos Aires.

De Marco, F., Pagliari, L., Degola, F., Buxa, S.V., Loschi, A., Dinant, S., Le Hir, R., Morin, H., Santi, S., and Musetti, R. 2016. Combined microscopy and molecular analyses show phloem occlusions and cell wall modifications in tomato leaves in response to 'Candidatus Phytoplasma solani'. J. Microsc. 263: 212-225.

De Storme, N., and Geelen, D. 2014. Callose homeostasis at plasmodesmata: molecular regulators and developmental relevance. Front. Plant Sci. 5: 138. https://doi.org/10.3389/fpls.2014. 00138

Fahn, A. 1982. Anatomía vegetal. Editorial Pirámide, Madrid.

Ford, E.S. 1942. Anatomy and histology of the Eureka lemon. Bot. Gaz. 104: 288-305.

Heslop-Harrison, Y., and Heslop-Harrison, J. 1981. The digestive gland of pinguicula: structure and cytochemistry. Ann. Bot. 47: 293-319.

Huff, A. 1983. Nutritional control of regreening and degreening in Citrus peel segments. Plant Physiol. 73: 243-249.

Huff, A. 1984. Sugar regulation of plastid interconversions in epicarp of Citrus fruit. Plant Physiol. 76: $307-312$ 
Iglesias, D.J., Cercós, M., Colmenero-Flores, J.M., Naranjo, M.A., Ríos, G., Carrera, E., Ruiz-Rivero, O., Llivo, I., Morillon, R., Tadeo, F.R., and Talón, M. 2007. Physiology of citrus fruiting. Braz. J. Plant Physiol. 19: 333-362.

Interdonato, R., Rosa, M., Nieva, C.B., González, J.A., Hilal, M., and Prado, F.E. 2011. Effects of low UV-B doses on the accumulation of UV-B absorbing compound and total phenolics and carbohydrate metabolism in the peel of harvested lemons. Environ. Exp. Bot. 70: 204-211.

Karnovsky, M.J. 1965. A formaldehyde glutaraldehyde fixative of high osmolality for use in electron microscopy. J. Cell Biol. 27: 137-138.

Koch, K.E., and Avigne, W.T. 1990. Postphloem, nonvascular transfer in citrus. Plant Physiol. 93: $1405-1416$.

Lee, J.Y. 2015. Plasmodesmata: a signaling hub at the cellular boundary. Curr. Opin. Plant Biol. 27: $133-140$.

Martin, F.W. 1959. Staining and observing pollen tubes by means of fluorescence. Stain Technol. 34: $125-128$.

Martinelli, T. 2008. In situ localization of glucose and sucrose in dehydrating leaves of Sporobolus stapfianus. J. Plant Physiol. 165: 580-587.

Matas, A.J., Agustí, J., Tadeo, F.R., Talón, M., and Rose, J.K.C. 2010. Tissue-specific transcriptome profiling of the citrus fruit epidermis and subepidermis using laser capture microdissection. J. Exp. Bot. 61: 3321-3330.

Medeira, M.C., Maiar, M.I., and Vitor, F. 1999. The first stages of pre-harvest 'peel pitting' development in 'Encore' mandarin. An histological and ultrastructural study. Ann. Bot. 83: 667673.

Merelo, P., Agustí, J., Arbona, V., Costa, M.L., Estornell, L.H., Gómez-Cardenas, A., Coimbra, S., Gómez, M.D., Pérez-Amador, M.A., Domingo, C., Talón, M., and Tadeo, F.R. 2017. Cell wall remodeling in abscission zone cells during ethylene-promoted fruit abscission in citrus. Front. Plant Sci. 8: 126. https://doi.org/10.3389/fpls.2017.00126

Nelson, N. 1944. A photometric adaptation of the Somogyi method for the determination of glucose. J. Biol. Chem. 153: 375-380. 
Nicolas, W.J., Grison, M.S., Trépout, S., Gaston, A., Fouché, M., Cordelières, F.P., Oparka, K., Tilsner, J., Brocard, L., and Bayer, E.M. 2017. Architecture and permeability of post-cytokinesis plasmodesmata lacking cytoplasmic sleeves. Nat. Plants, 3: 17082. https://doi.org/10.1038/nplants.82

Podazza, G., Rosa, M., González, J.A., Hilal, M., and Prado, F.E. 2006. Cadmium induces changes in sucrose partitioning, invertase activities and membrane functionality in roots of rangpur lime (Citrus limonia 1. Osbeck). Plant Biol. 8: 706-714.

Prado, F.E., Boero, C., Gallardo, M., and González, J.A. 2000. Effect of $\mathrm{NaCl}$ on growth germination and soluble sugars content in Chenopodium quinoa Willd. seeds. Bot. Bull. Acad. Sin. 41: 27-34.

Roberts, I.M., Boevink, P., Roberts, A.G., Sauer, N., Reichel, C., and Oparka, K.J. 2001. Dynamic changes in the frequency and architecture of plasmodesmata during the sink-source transition in tobacco leaves. Protoplasma 218: 31-44.

Roe, J.H., and Papadopoulos, N.M. 1954. The determination of fructose-6-phosphate and fructose-1,6diphosphate. J. Biol. Chem. 210: 703-707.

Rosa, M., Hilal, M., González, J.A. and Prado, F.E. 2004. Changes in soluble carbohydrates and related enzymes induced by low temperature during early developmental stages of quinoa (Chenopodium quinoa) seedlings. J. Plant Physiol. 161: 683-689.

Ross-Elliott, T.J., Jensen, K.H., Haaning, K.S., Wager, B.M., Knoblauch, J., Howell, A.H, Mullendore, D.L., Monteith, A.G., Paultre, D., Yan, D., Otero, S, Bourdon, M., Sager, R., Lee, J.Y., Helariutta, Y., Knoblauch, M., and Oparka, K.J. 2017. Phloem unloading in Arabidopsis roots is convective and regulated by the phloem-pole pericycle. Elife 6: e 24125.

Ruiz, V.E., Interdonato, R., Cerioni, L., Albornoz, P., Ramallo, J., Prado, F.E., Hilal, M., and Rapisarda, V.A. 2016. Short-term UV-B exposure induces metabolic and anatomical changes in peel of harvested lemons contributing in fruit protection against green mold. J. Photochem. Photobiol. B: Biol. 159: 59-65.

Sadka, A., Shlizerman, L., Kamara, I., and Blumwald, E. 2019 Primary metabolism in citrus fruit as affected by its unique structure. Front. Plant Sci. 10: 1167. https://doi:org/10.3389/fpls. 01167 
Sager, R., and Lee, J.Y. 2014. Plasmodesmata in integrated cell signalling: insights from development and environmental signals and stresses. J. Exp. Bot. 65: 6337-6358.

Taiz, L., Zeiger, E., Moller, I.M., and Murphy, A. 2015. Plant physiology and development. Sinauer Associates, Sunderland.

Venable, J.R., and Coggeshall, R. 1965. A simplified lead-citrate stain for use in electron microscopy. J. Cell Biol. 25: 407-408.

Zarlavsky, G.E. 2014. Histología vegetal: Técnicas simples y complejas. Sociedad Argentina de Botánica, Argentina. 


\section{Figure legends}

Figure 1. Appearance of lemons used for assays and peel anatomy. (A) Photograph of representative green immature (left) and yellow mature (right) lemons. (B) Cross-section of yellow lemon peel stained with toluidine blue. Inset: starch grains in albedo cells, visualized with polarized light. (C) and (D) Cross-section of unstained flavedo tissue of green and yellow lemons, respectively. cu: cuticle; ep: epidermis; co: collenchyma; pa: parenchyma; vb: vascular bundle; oc: oil cavity; cr: crystals.

Figure 2. Parenchymatic cells of flavedo tissue. Cross-sections of lemon peel stained with blue astrasafranin. (A) and (C) Green lemon samples with discontinuous of cell walls (primary pit fields) that resemble string of beads. (B) and (D) Yellow lemon samples showing homogeneous cell walls, without interruptions. (Inset in C) Detail of cytoplasmic flow in cells of green lemon. c: closed primary pit fields; o: open primary pit fields; cf: cytoplasmic flow.

Figure 3. Parenchymatic cells of albedo tissue. Cross-sections of lemon peel stained with blue astrasafranin. (A) Green and (B) yellow lemon samples, presenting discontinuous cell walls that look like a string of beads. $\mathbf{0}$ : open primary pit fields.

Figure 4. Ultrastructure of flavedo parenchymatic cells and callose deposition. Transmission electron microscopy images of flavedo cross-sections denoting (A) cell walls with interruptions associated to PD in immature lemons or (B) without interruptions in mature lemons (c: closed PD; o: open PD). Epifluorescence microscopy of cross-sections stained with aniline blue showing (C) small dots of low brightness in immature lemons or (D) bright dots and lines through the cell walls (see arrow) in mature lemons.

Figure 5. Phloem cells from the peduncle region of lemon. Longitudinal sections stained with brilliant cresyl blue and visualized using light microscopy. (A) Green or (B) yellow lemon sections showing sieve plates without or with callose deposits, respectively. cd: callose deposit.

Figure 6. Cell wall-bound invertase activity of peel tissues. Enzymatic activity measured in flavedo and albedo tissues from immature and mature lemons. Data represent the means of 3 independent experiments performed in triplicate. Different letters indicate significant differences according to Tukey's test $(p<0.01)$. 
Figure 7. In situ localization of sucrose in lemon peel and apoplastic and symplastic contents in flavedo. Red insoluble INT-formazan associated with the presence of sucrose is shown in crosssections of peel of immature (A) and (C) and mature (B) and (D) lemons. (E) Sucrose content in the apoplastic and symplastic parts of flavedo tissue. Data represent the means of 3 independent replications performed in triplicate. Different letters indicate significant differences according to Tukey's test $(p<0.01)$.

Figure 8. Scheme of photosynthates transport pathways in peel of immature and mature lemons. Left in upper panel: in immature lemons, phloem tubes in the vascular bundles (vb) allow circulation of phloem from plant to fruit (dashed line). Left in bottom panel: in mature lemons, closed phloem tubes in the $\mathrm{vb}$ at the level of the peduncle interrupt the communication from plant to fruit and closed PD (black bands) block the symplastic pathway in flavedo tissue. Right diagrams in panels: transport of photosynthates in parenchymatic cells of albedo and flavedo tissues via apoplastic (dashed arrow), transcellular (grey arrow), and symplastic (black arrow) pathways. In flavedo of mature lemons, PD are closed (black bands) and cell wall-bound invertase (WI) activity related to transcellular transport increases. In these lemons, albedo function as a source tissue to provide assimilates to flavedo. 


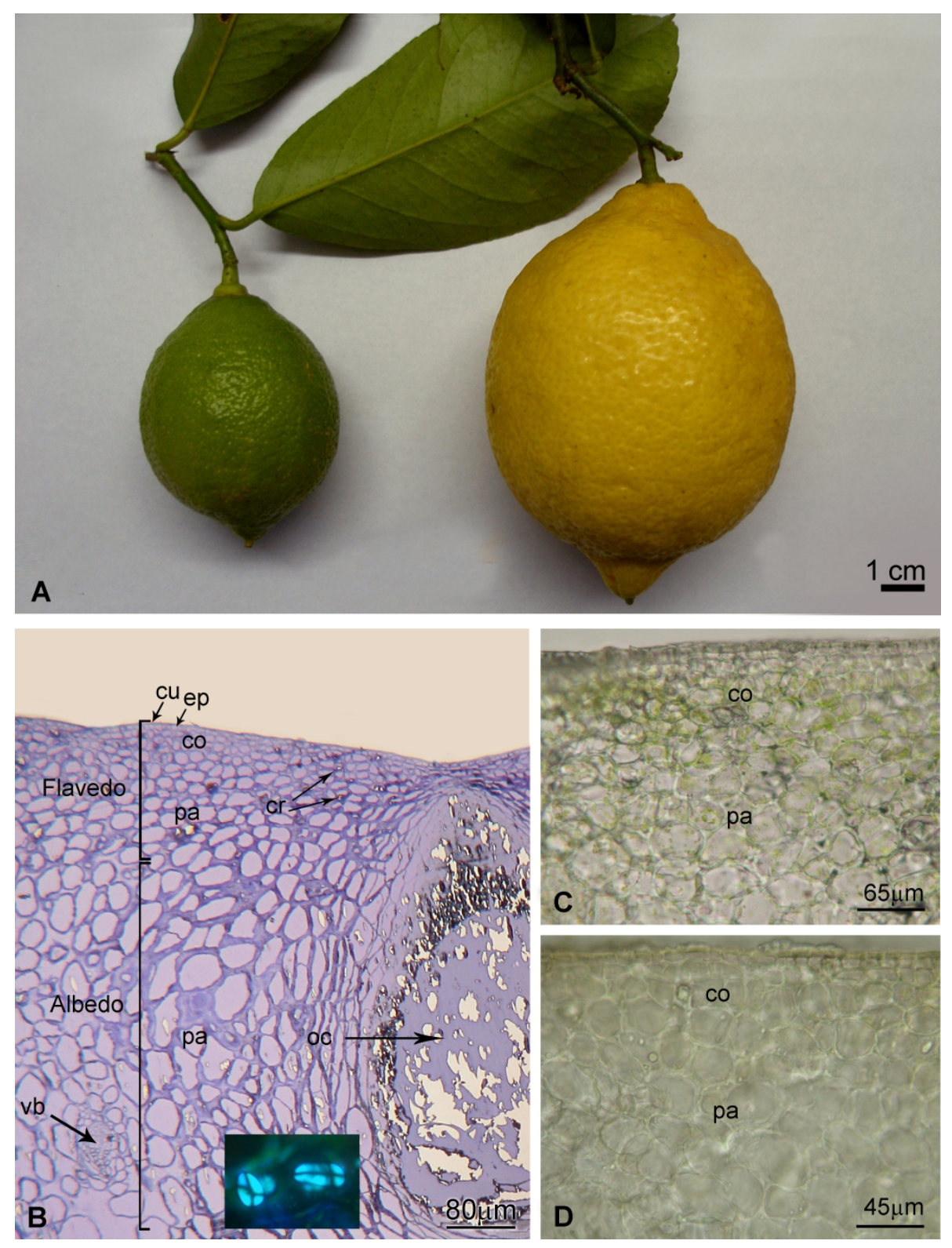

Figure 1

$137 \times 181 \mathrm{~mm}(600 \times 600 \mathrm{DPI})$ 

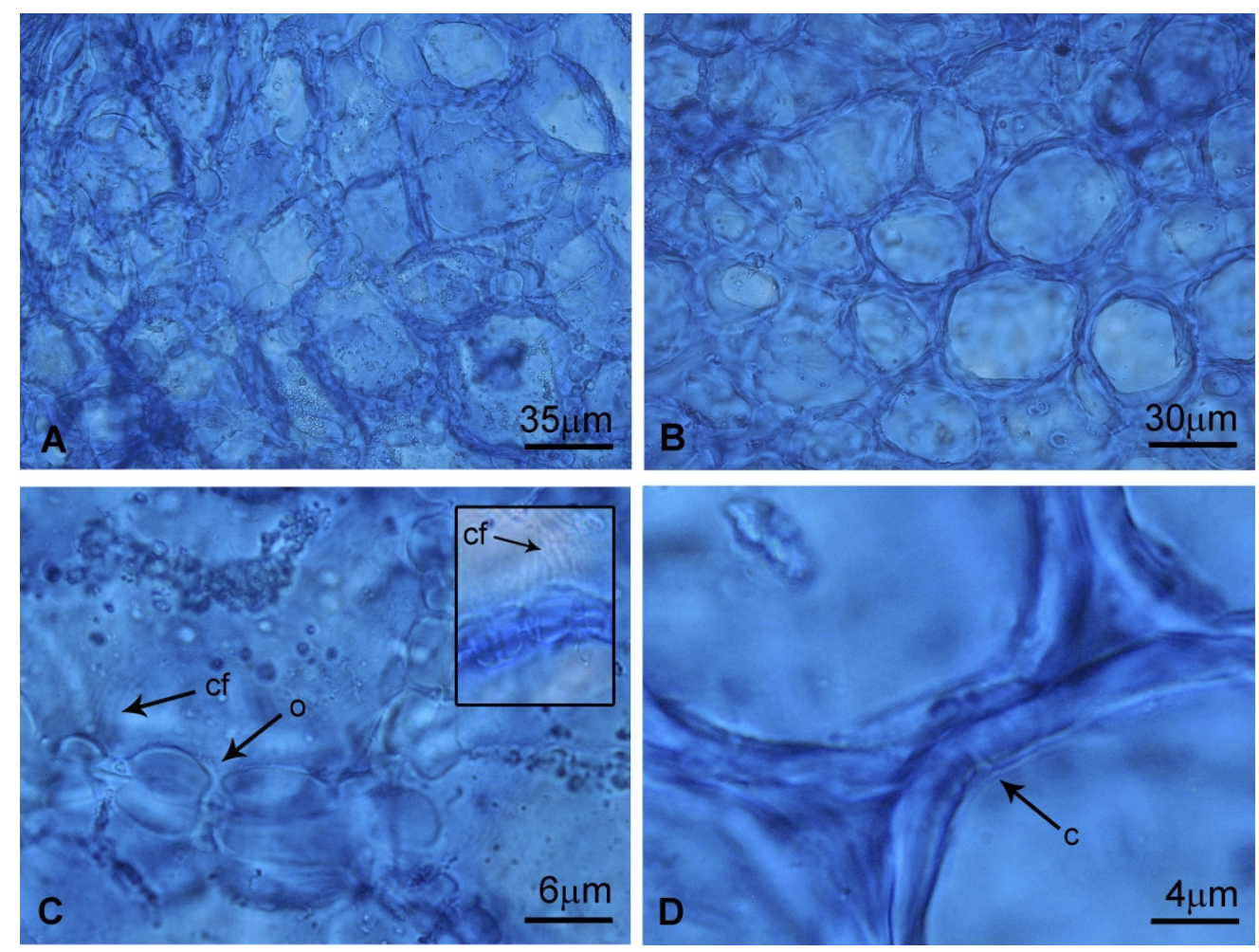

Figure 2

$139 \times 105 \mathrm{~mm}(600 \times 600 \mathrm{DPI})$ 

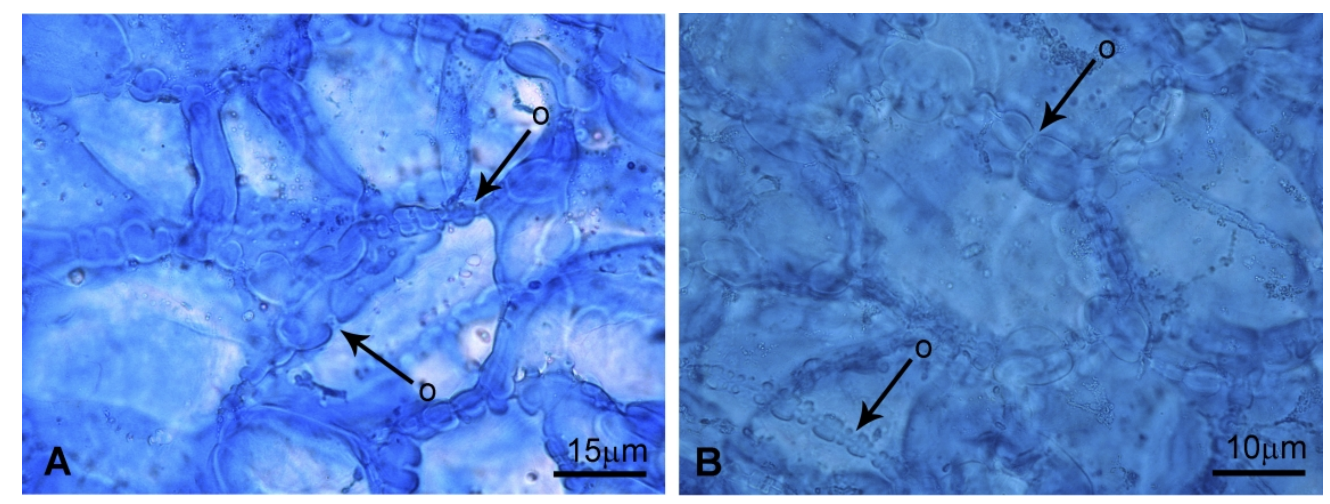

FIgure 3

$139 \times 51 \mathrm{~mm}(600 \times 600$ DPI $)$ 

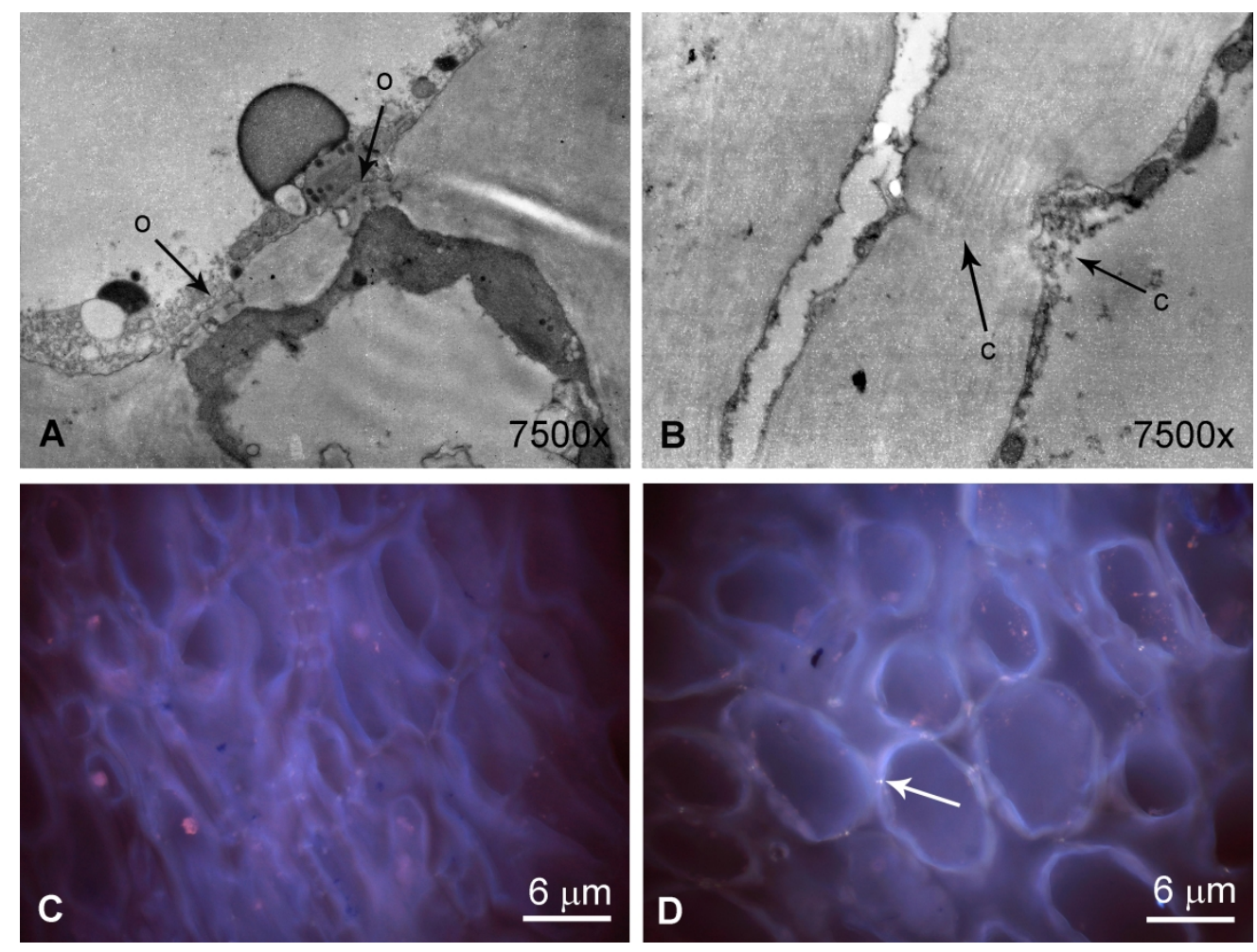

Figure 4

$139 \times 105 \mathrm{~mm}(600 \times 600 \mathrm{DPI})$ 

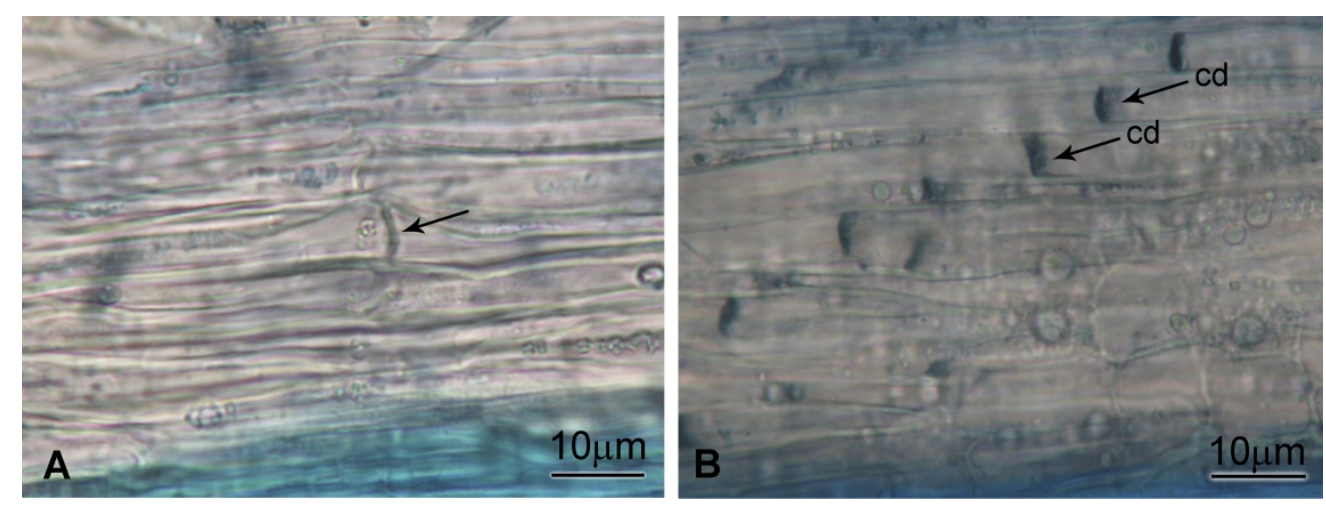

Figure 5

$139 \times 51 \mathrm{~mm}(600 \times 600$ DPI $)$ 


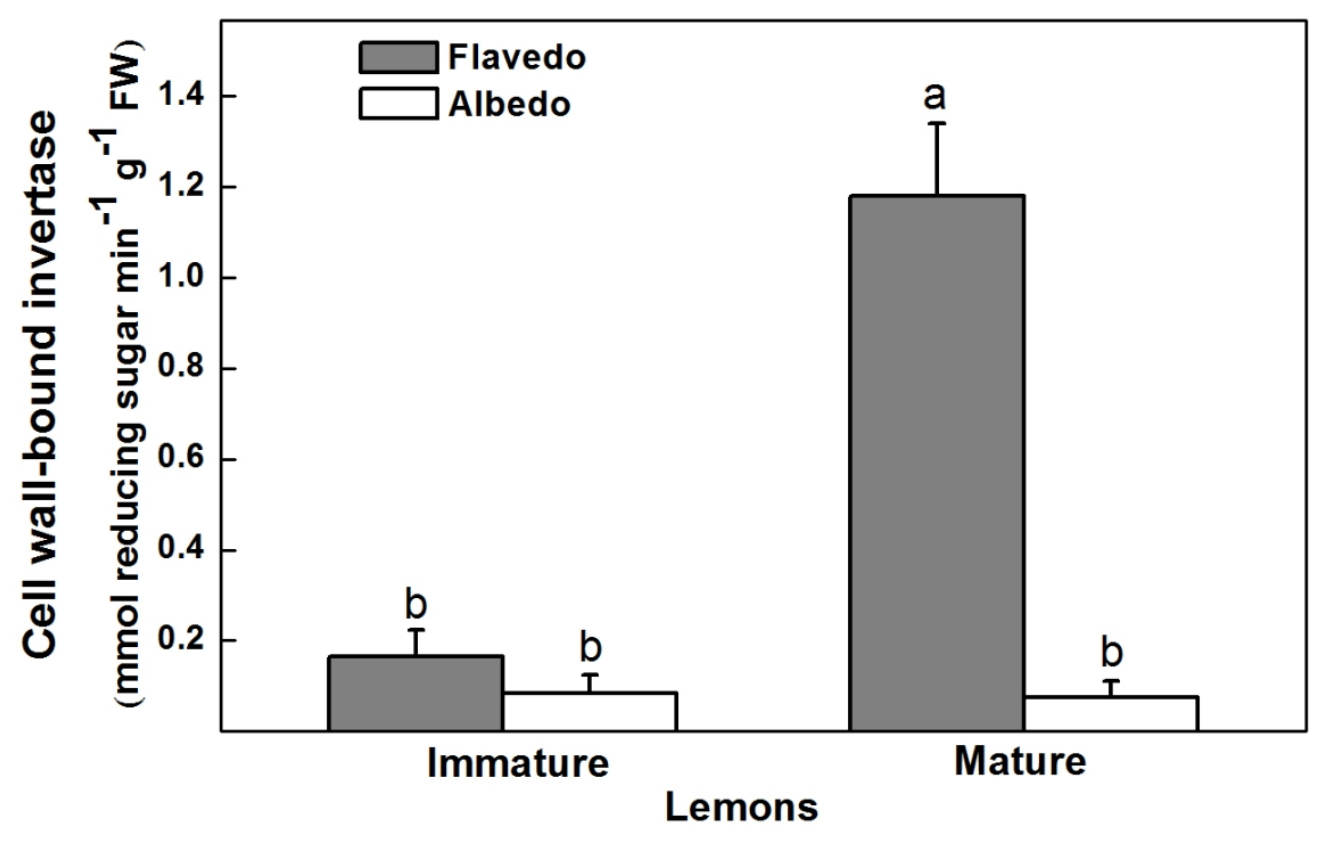

Figure 6

$215 \times 135 \mathrm{~mm}(150 \times 150 \mathrm{DPI})$ 

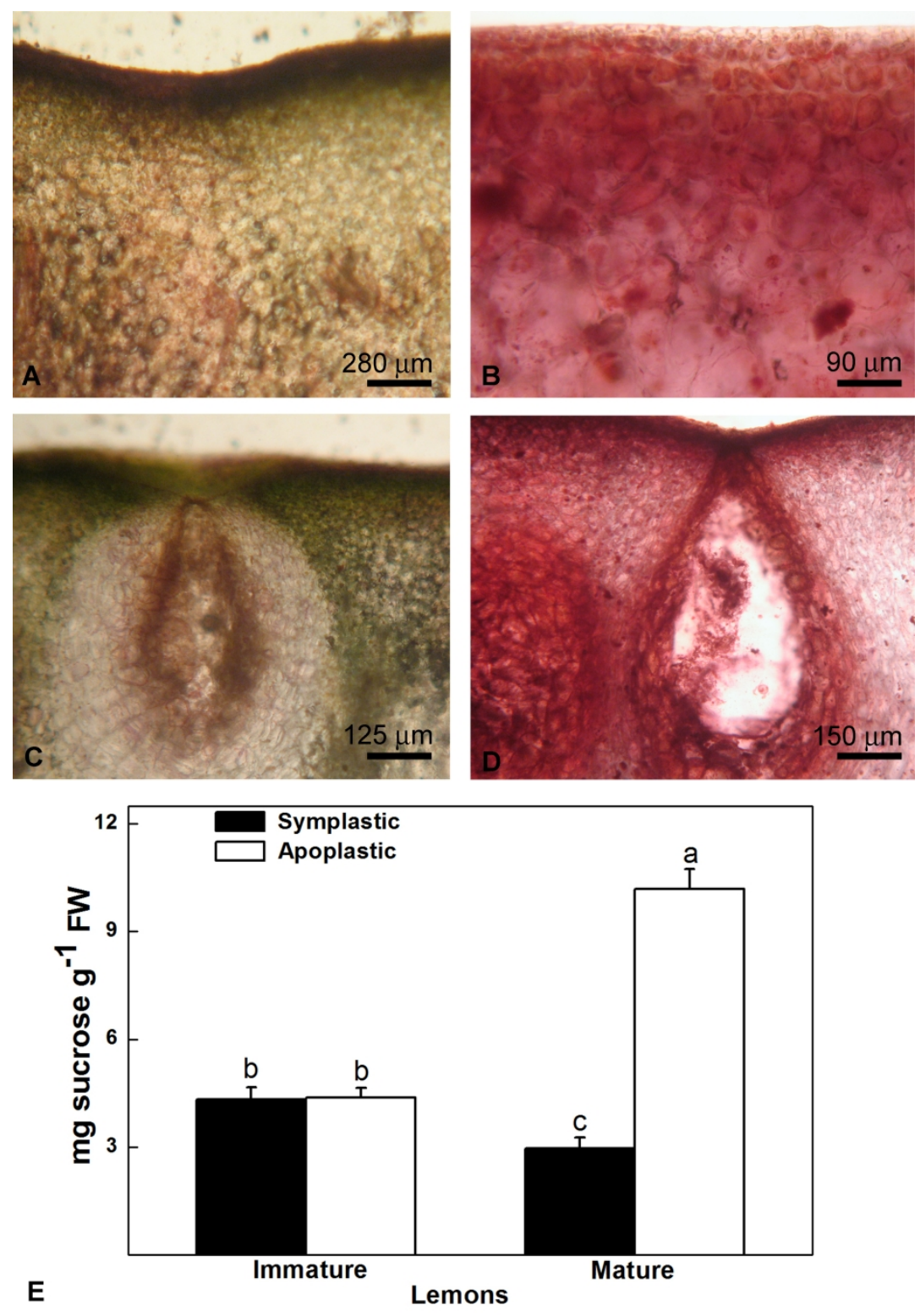

Figure 7

$139 \times 205 \mathrm{~mm}(600 \times 600$ DPI $)$ 


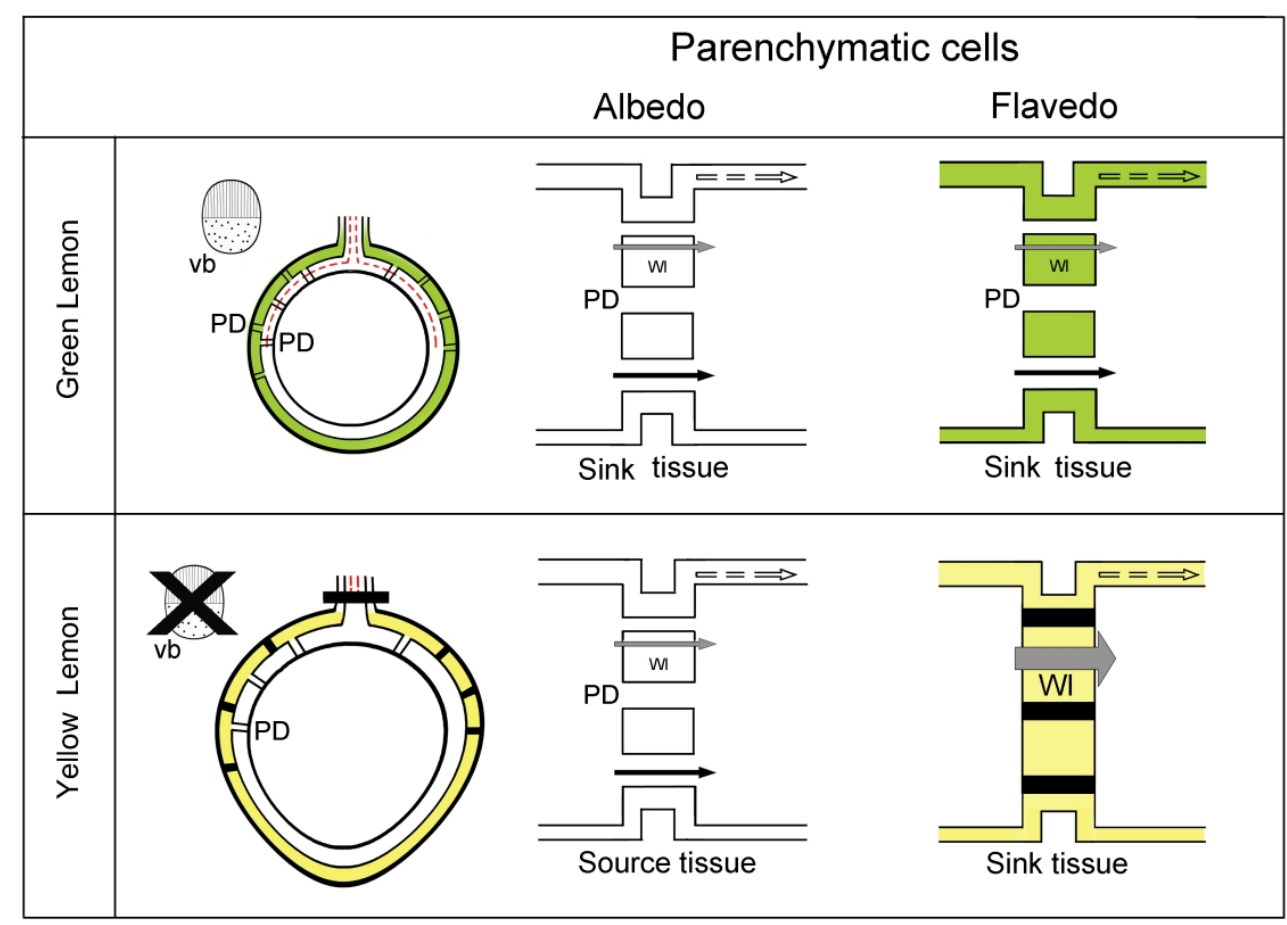

Figure 8

$139 \times 104 \mathrm{~mm}(600 \times 600$ DPI $)$ 